\title{
A strategy to identify genomic expression at single-cell level or a small number of cells
}

\author{
Biaoru Li \\ Department of Biochemistry, School of Medicine \\ Case Western Reserve University \\ 10900 Euclid Ave. Cleveland, OH 44106, USA \\ Tel: 12163681634 \\ Fax: 14405420186 \\ E-mail: bxl26@po.cwru.edu
}

Keywords: genome, genomic expression, genomic expression analysis at single cell, single cell.

Recent advances in functional genomics allow us to estimate the expression of several thousands of genes in the mammalian genome. Techniques such as microarrays, expressed tag sequencing (EST), serial analysis of gene expression (SAGE), subtractive cloning and differential display (DD), and two-dimensional electrophoresis gel have been extensively used to screen and analyze parallel gene expression. Some pathological processes, for example, tumorigenesis and solid tumour growth, in which the former is derived from a single-cell and the latter has a mixed-cell problem, present new challenges to the limit of these functional genomic techniques. To fully understand the functions of cells in tumorigenesis or in heterogeneous solid tumour masses, it is essential for scientists and physicians to develop a strategy to identify genomic expression profiles for a single-cell or for small numbers of cells. In this article, we review recently developed methods that enable functional genomic analysis at the single-cell or multicell level. In addition, the paper will review different techniques of single-cell genomic expression at the level of DNA, mRNA, protein and post-translational modifications.

A major task of functional genomics is to study cell function at the level of mRNA and protein expression. Routine approaches of identification and quantification include DNA microarrays, expressed tag sequencing (EST), serial analysis of gene expression (SAGE), subtractive cloning and differential display (DD) for mRNA, and twodimensional gel electrophoresis, mass spectrometry and protein microarray based antibody-binding for protein. Traditionally, each approach requires relatively large numbers of cells (Kim, 2002; Steinert et al. 2002).

These traditional methods have been extensively utilized to study parallel gene expression in different cell lines. It is known that cell lines used as models in some fields, such as tumorigenesis, have limitations. For example, after certain tumour cell lines go through several hundred passages, many properties of tumour cells have changed; the genome expression from the cell line does not accurately reflect properties of in vivo tumour cells. However, some primary tumour cells from tumour tissue display the intrinsic function and properties of tumour cells. In addition, tumour cell formation and development involves the accumulation of multiple-gene mutations as a tumour grows from a single cell or a very small number of cells (clonality) (Boultwood and Wainscoat, 2001; Wood, 2001). If the single cell or a small number of cells from primary tumour cells can be employed for genome analysis, it can address questions such as how tumour cells form, how tumour tissue develops, and how some agents can block tumour formation and development. Based on the requirement for analyzing tumorigenesis, some strategies have been developed to study functional genomics at the single-cell level.

In order to clearly introduce functional genomic analysis in the single cell, we will briefly review traditional functional genomic methods and then discuss genomic analysis at the unicell level.

\section{TRADITIONAL GENOMIC METHODS}

\section{Genome-wide monitoring of levels of DNA, mRNA} and protein

Many traditional techniques used to measure gene expression are directly related to the quantitative detection of mRNA and protein among parallel samples. Relating these techniques to the central dogma (Figure 1) can help us to categorize these methods. Briefly, they can be divided into four fields: (1) DNA level such as genomic sequencing and single nucleotide polymorphism (SNP); (2) mRNA level including microarray, expressed tag sequencing (EST), serial analysis of gene expression (SAGE), 
subtractive cloning and differential display (DD); (3) protein level, for example, two-dimensional gel electrophoresis, mass spectrometry, and protein arrays based on antibody binding; and (4) post-translational level such as protein-protein interaction via the yeast two-hybrid or repressor system (Cordwell et al. 2000; Dean, et al. 2002; Forde and McCutchen-Maloney, 2002; Meehan and Welch, 2003; Shaknovich, 2003).

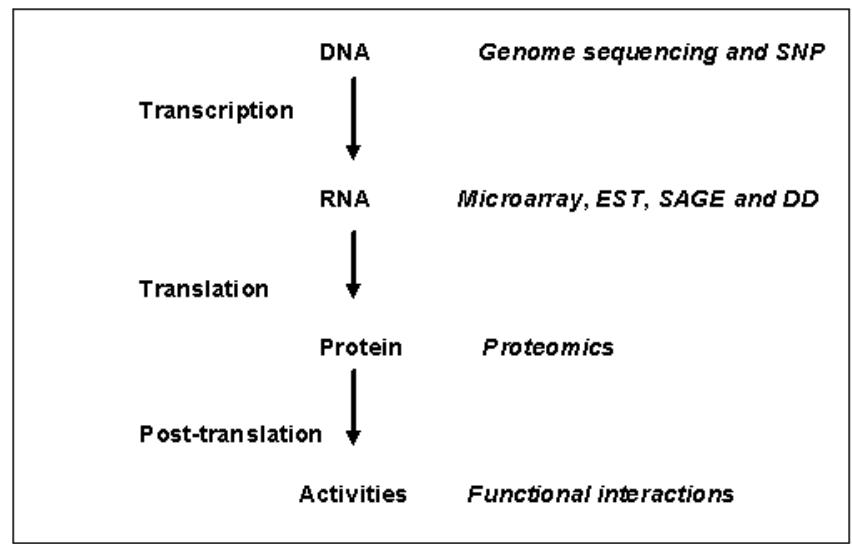

Figure 1. Traditional genomic study.

In general, the extreme stability of genomic DNA allows it to be used to examine single nucleotide polymorphisms (SNP). A large-scale analysis of SNPs can help use to identify genes affecting variant human phenotype, including different diseases and drug responses in some individuals. Although genomic DNA has these advantages, it is not extensively used for gene expression and gene regulation at the cellular level (Lilleberg, 2003).

Functional genomic studies at the mRNA level have demonstrated tremendous development in the past few years, evidenced by the development of spotted-based microarray, library-based EST and SAGE and gel-based differential-display. These mRNA-based methods are critically important for screening and analysis of mRNA regulation and deregulation in whole cell systems. However, such approaches will overlook changes in posttranscriptional regulation, protein expression level, and post-translational modifications (Weigl et al. 2003).

Further, emerging proteomic strategies such as twodimensional gel electrophoresis and mass spectrometry will provide proteomic information regarding protein expression levels and post-translational modifications. However, protein stability and small concentration of protein available for the study will limit the application of these traditional methods at the single-cell level (Murray et al. 2002).

\section{Material influencing genomic study at the level of DNA, mRNA and protein}

Before discussing genomic expression at the single-cell level or at level of a small number of cells, scientists should carefully consider issues of material sources and procurement. In general, human tissue is available from biopsy or surgical specimens. These specimens can be available in 3 different forms: they can be freshly obtained, frozen, or embedded in paraffin. First, and perhaps most important, the quality and intactness of biomaterials including DNA, mRNA and protein need to be addressed here. According to routine specimen procedures involving genomic study, there is little doubt that fresh tissues or culture cells are the best choice to analyze genome expression. Fixed tissues from animals and humans used in gene expression have yielded inconsistent results. Some papers demonstrate variable results with the use of fixed tissue for expression analysis, while others have successfully measured levels of gene expression. Interestingly, some reports demonstrate no difference in either the quality or intactness of RNA extracted from fixed tissue (by formalin and ethanol) and from standard frozen tissue when evaluated by reverse transcription combined with PCR amplification (Morita et al. 1994; Ren et al. 2000).

A second area of importance is the quantitative requirement of DNA, mRNA and protein from biomaterials. Varying levels of DNA, mRNA, and protein yield have resulted in different results due to the use of different models of equipment, the use of different protocols to purify DNA, mRNA and protein and variability in user expertise. Here, I include minimal concentration requirements for some emerging techniques (Table 1). The concentrations of DNA, RNA, protein and the approximate cell numbers are based on some traditional methods. The details of developments regarding sensitivity and resolution of the parallel expression of genome will be discussed in the next section.

\section{FUNCTIONAL GENOMICS AT SINGLE-CELL LEVEL}

Specimens of animal and human tissue often contain multiple cell types with different gene expression profiles. Theoretically and practically, potentially important findings in the gene expression profiles in the multiple cell types will be obscured or unclear. Therefore, studies of representative single cells will provide the most precise analysis possible of these subtle gene expression patterns. Here, in order to discuss functional genomics in single cells clearly, the following three fields: (1) single-cell sampling; (2) mRNA and protein isolation or amplification from a single cell; and (3) application of genomic expression of single cells, will be systematically reviewed.

\section{Single-cell sampling}

As shown in Table 2, flow-cytometric cell sorting and laser-based microdissection of tissues now provide good methods to isolate single cells for gene expression profiling. In flow cytometry, cells in solution are labeled 
Table 1. Traditional functional genomics *.

\begin{tabular}{|c|c|c|c|c|}
\hline Methods & Minimum Material & Throuqhput & Sequencinq & Application \\
\hline \multicolumn{5}{|l|}{ Sequencing base } \\
\hline EST & 1-5 ug polyA RNA & High & High & gene expression \\
\hline SAGE & 1-5 ug polyA RNA & High & High & gene expression \\
\hline \multicolumn{5}{|l|}{ Gel base } \\
\hline $\mathrm{DD}$ & 10-100 ng polyA RNA & Medium & Low & Parallel gene expression \\
\hline \multicolumn{5}{|l|}{ Colony base } \\
\hline Subtractive cloning & 10-100 ng polyA RNA & Medium & Low & Parallel gene expression \\
\hline \multicolumn{5}{|l|}{ Hybridization base } \\
\hline Microarray & $>1$ ug polyA RNA & High & $\mathrm{N} / \mathrm{A}$ & Parallel gene expression \\
\hline \multicolumn{5}{|l|}{ Protein base \# } \\
\hline Two-D gel electrophoresis & $10^{6}-10^{7}$ cells & High & N/A & Parallel protein expression \\
\hline Mass spectrometry & $10^{5}-10^{6}$ cells & High & N/A & Parallel protein expression \\
\hline \multicolumn{5}{|l|}{ Functional array } \\
\hline Repressor system & $\mathrm{N} / \mathrm{A}$ & $\mathrm{N} / \mathrm{A}$ & Low & Protein-protein reaction \\
\hline Yeast- library system & N/A & N/A & Medium & Protein \\
\hline
\end{tabular}

* Sample concentration: Claudio et al. 1998; Trendelenburg et al. 2002; Bosch et al. 2000; Carulli, et al. 1998; Oppermann et al. 2000. \# Some journals used as protein concentration

with fluorescent signals. These signals can be derived from a specific biomarker such as a tumour antigen attached to an antibody that is labeled with a fluorescent signal or a recombinant DNA construct encoding modified proteins with a fluorescent signal. At present, multi-coloured fluorescence-activated cell sorters can selectively separate and collect homogeneous cells with identical phenotypic features in a collection tube in order to increase sensitivity for gene expression profile in a given cell type (Ormerod, 2000). Although flow-cytometric cell sorting and multicolour fluorescence-activated cell sorters can isolate and sort homogeneous cells, there are three limitations to using these techniques: (1) some cell types such as neurons are not amenable to separation and sorting by flow-cytometry; (2) internal cell localization of sub-cellular components cannot be well-defined using flow cytometry; and (3) the microenvironment of a cell (such as a good blood supply or a bad blood supply) cannot be evaluated and studied using flow cytometry.

The microdissection technique, in part, avoids these problems. The use of lasers in tissue microdissection was reported as early as 1976 (Meier-Ruge et al. 1976), and it has increasingly been applied in single-cell microdissection in recent years. In contrast to flow-cytometric cell sorting, microdissection allows for both rapid in vivo localization and the ability to analyze the cellular microenvironment (Schutze and Lahr, 1998). At present, three microdissection methods have been developed:

(1) laser-assisted mechanical tissue microdissection;

(2) laser pressure catapult microdissection;
(3) laser capture microdissection.

Laser-assisted mechanical tissue microdissection can focus on small target cell areas, reducing the chance of contamination with neighbouring cells (Emmert-Buck et al. 1996). Although the concept of using a laser to dissect out individual cells is quite simple, the technique is laborious. Laser pressure catapult microdissection concentrates on an interesting region with a high-energy cutting laser. First, a low-power laser sets the depth of the tissue section; a pressure wave then separates the targeted tissue from the slide and catapults it into a receptacle. The high precision of the thin-beam laser is sufficient to isolate sub-cellular targets such as chromosomes - a distinct advantage for this technique. The absence of physical contact between the surrounding tissues and the collection apparatus results in a much lower incidence of contamination. In laser capture microdissection, a thin ethylene vinyl acetate film is mounted on the tissue section. After an infrared laser heats and melts a cell of interest, the re-solidified plastic film binds directly to this cell and catches it. Potential problems of laser capture microdissection as shown in Table 2 include damage to the target cell by contact with heat film (Fend et al. 1999). At present, all of these methods are commercially available for laboratory and hospital.

\section{mRNA and protein isolated and amplified from single cells}

mRNA isolation and amplification from single cells. The quantity of mRNA in a single cell is 
Li, B.

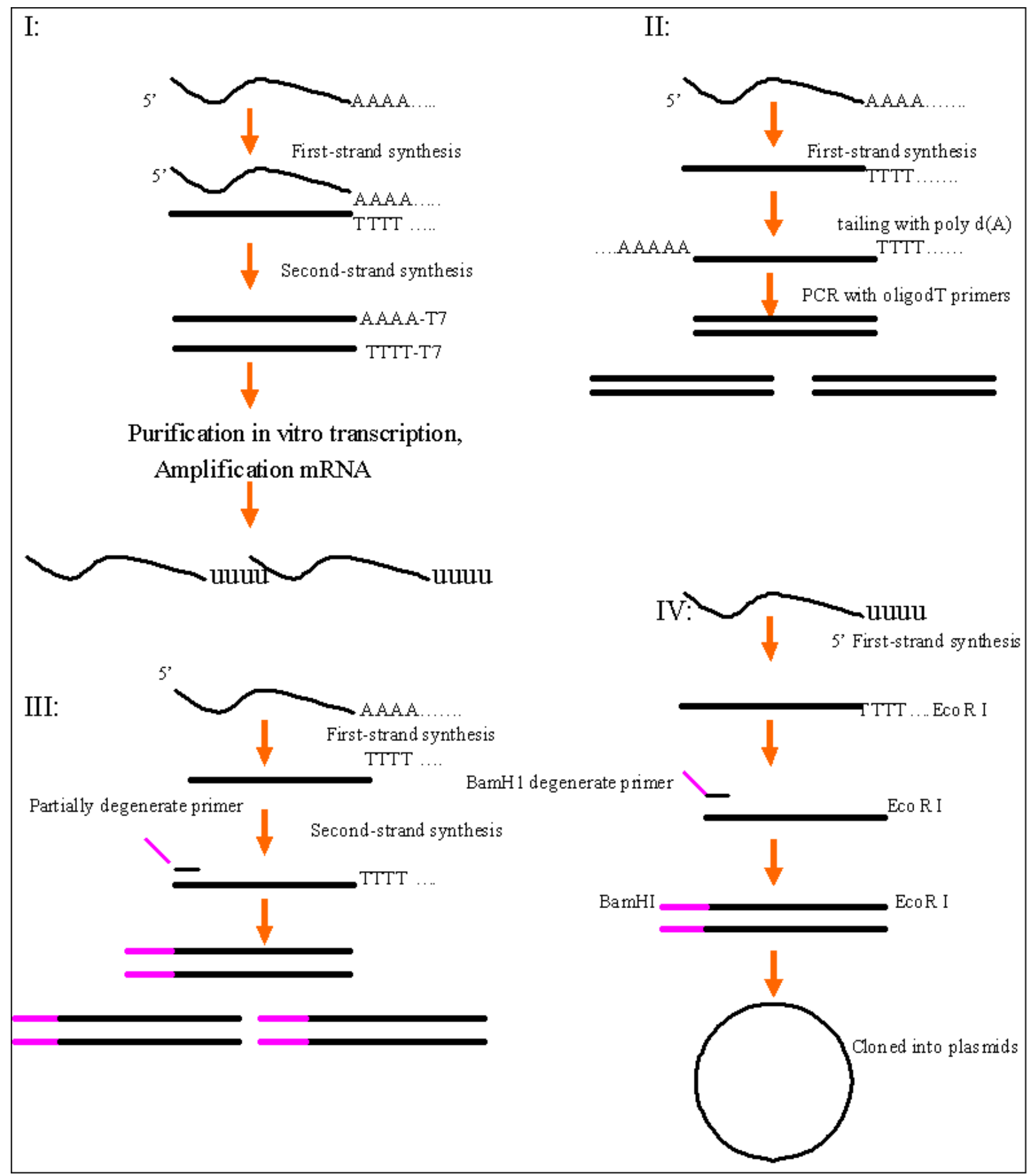

Figure 2. mRNA amplification from single cells.

approximately $1.0 \mathrm{pg}$ (about $5 \times 10^{5}$ molecules) (Ambion, 2004). Although some scientists try to isolate RNA from single cells, we prefer to use a crude cell lysate without purifying procedures (Klebe et al. 1996). This protocol has two important advantages. First, it ruptures the cells and releases the RNA directly into a cell lysis buffer without loss of RNA. Moreover, the heating step to rupture cells inactivates endogenous RNase, further protecting RNA from degradation. Theoretically, in order to observe subtle differences in parallel gene expression, genome information 
amplification should be applied in single-cell studies. At present, there are two strategies to employ genome information amplification: mRNA amplification (aRNA) and PCR-based cDNA amplification.

The aRNA procedure begins with total RNA or poly(A) RNA that is reverse transcribed using an oligo (dT) primer containing a T7 RNA polymerase promoter sequence. After first-strand synthesis, the reaction is treated with RNase $\mathrm{H}$ to fragment the mRNA. These fragments serve as primers during a second-strand synthesis reaction that produces a double-stranded DNA template for transcription. rRNA, mRNA fragments and primers are removed before using the cDNA template to produce linearly amplified aRNA. The amplification yields can reach 1000-5000 fold following two rounds of in vitro transcription (Figure 2-I). RNA amplification and is commercially available and has been increasingly reported in gene expression studies (Eberwine, 1996).

PCR-based amplification has two protocols: specific profile and global profile applications. Specific profile methods such as rtPCR or multiplex rtPCR reactions are sensitive at the single-cell level, especially in nested PCR. Because the genes studied this way are pre-selected, it can only be applied to known genes. In order to overcome the problem, global PCR-based approaches have been developed in genomic analysis. One approach is homomeric tailings, and another is $3^{\prime}$-(3-primer-end) amplification (TPEA). The former (Figure 2-II) (Toellner et al. 1996) uses terminal deoxynucleotide transferase-generated homomeric 3' tails to the first-strand cDNA. After rtPCR and 3' tailing addition and PCR amplification, it has been applied to the analysis of single-cell global gene expression. Even though homomeric tailings can be used effectively in global profile analysis, many of the cDNA copies are not full length and shorter cDNAs are preferentially amplified. 3-primer-endamplification (TPEA, Figure 2-III) (Dixon et al. 1998) is a partially randomized amplification of mRNA using an oligo-dT primer together with a 5' primer containing a random pentamer. It can enable the detection of both highand low-abundance mRNA transcripts from single cells. Because TPEA also has a 3' bias, full-length cloning is more difficult. Moreover, only 40 to 50 genes can be analyzed in samples derived from single cells.

We have also developed a more facile strategy to screen the genome at the single cell level. To illustrate, three techniques (RNA directly from cell lysis, randomized primer design as differential display and single cell genome cloned into plasmids) are simultaneously combined (Li et al. 2000). Following cell lysis and reverse transcription PCR, a 3' end oligo (dT) $)_{n}$ primer and a set of 5' end arbitrary primers (both containing restriction enzyme terminals) are used in an amplification by PCR. After double digestion, the genome from a small number of cells is introduced into plasmids and transformed into cells. As Figure 2 and Figure 3 indicate, subtractive hybridization from a reference cell genome is employed in the modified method so that artefacts of cDNA amplification from test cells are minimized ( $\mathrm{Li}$ et al. 2002). The technique has been used in genome expression analysis from 10 to 100 cells. The advantage is that the expression results are very sensitive and accurate because they exclude problems of artefacts. The disadvantage is similar to TPEA, that is, expression has a 3' bias (Figure 2-IV). Over the past two years, as aRNA techniques have been developed, cDNA detection sensitivity has significantly increased so that we can use either cells from microdissection or single cells obtained from culture to analyze their genome expression (Figure 3) (Zhang et al. 2004).

Protein signal amplification from a single-cell. Traditional methodologies for protein detection and quantification include two-dimensional gel electrophoresis, mass spectrometry, and antibody (Ab) binding. As we discussed previously, the application of these traditional proteomics-oriented technologies at the single-cell level has been limited because each methodology needs relatively large amounts of tissue.

Table 2. Single-cell sampling.

\begin{tabular}{|l|l|l|}
\hline \multicolumn{1}{|c|}{ Methods } & \multicolumn{1}{|c|}{ Advantages } & \multicolumn{1}{|c|}{ Disadvantages } \\
\hline Flow-cytometric cell sorting & Large quantity of cells; rapid separation & $\begin{array}{l}\text { Limit in some cells such as neuron } \\
\text { without microenvironment data }\end{array}$ \\
\hline Laser-assisted mechanical microdissection & $\begin{array}{l}\text { Very little contamination with microenvironment } \\
\text { data }\end{array}$ & Laborious \\
\hline Laser-catapult microdissection & $\begin{array}{l}\text { Very little contamination with microenvironment } \\
\text { data }\end{array}$ & Special slides \\
\hline Laser-capture microdissection & $\begin{array}{l}\text { Very little contamination with microenvironment } \\
\text { data }\end{array}$ & Theoretical damage to the target cell \\
\hline
\end{tabular}


Li, B.

The development of protein arrays using antibody-binding technology has presented a new opportunity to study protein expression at the single cell level. Recently, two protein array techniques have rapidly been extended. The first is the use of intact antibodies, antibody fragments (single-chain fragment variable $(\mathrm{ScFv})$ fragments) or exocyclic peptide-based complementarity determining region (CDR) subunits as antigen detectors. The second is the $\mathrm{Ab}$ used as amplification signals. In order to detect protein and peptide molecules, several Ab signal amplifications have been successfully employed in order to improve sensitivity. For example, immuno-PCR and T7 RNA amplification have been reported in several journals. In the former, the PCR technology is combined with

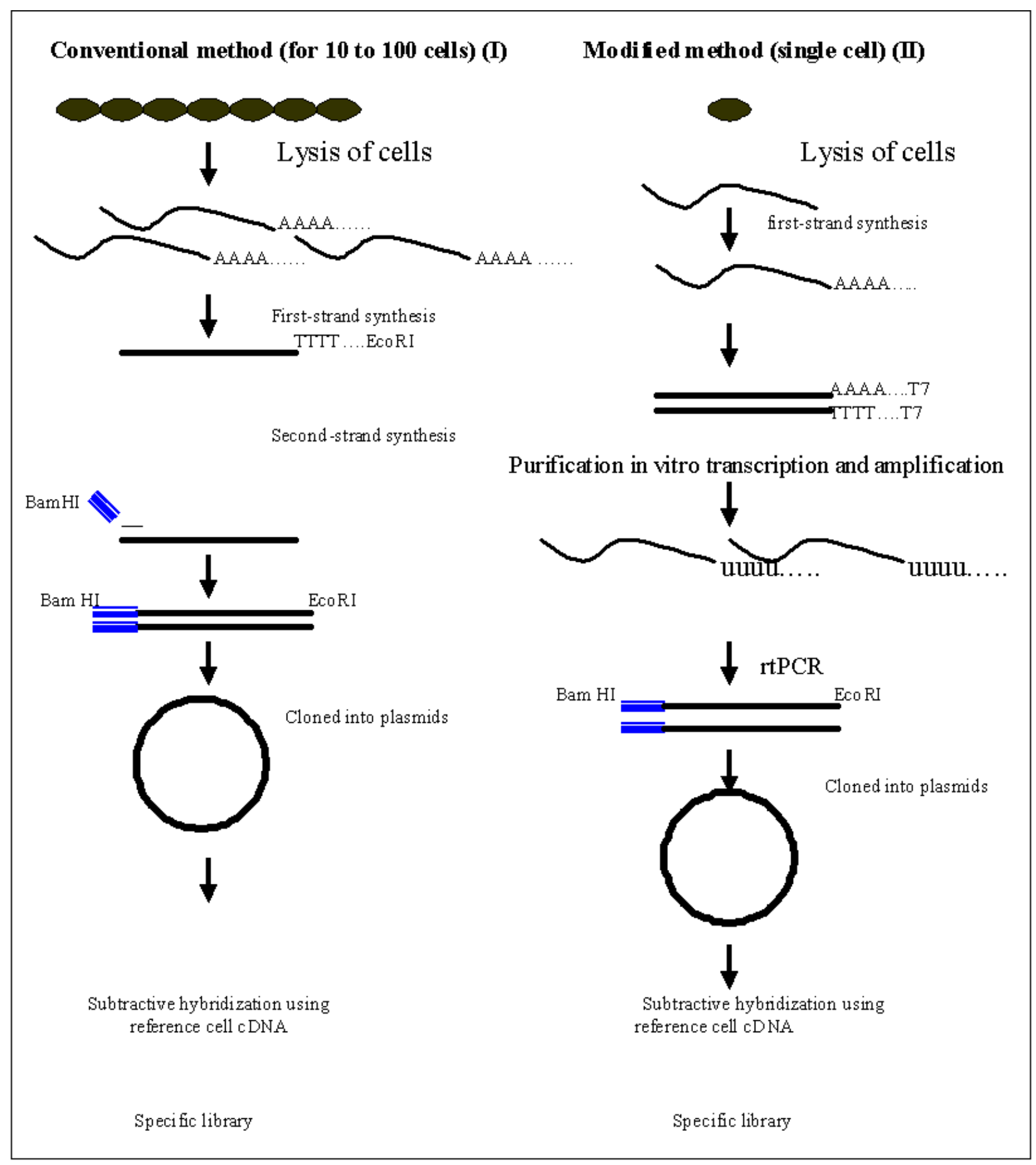

Figure 3. A strategy of genome library from single cells. 
conventional immuno-detection methods as shown in Figure 4(A) (McKie et al. 2002). Streptavidin is added to a biotinylated Ab-antigen complex whereupon a known biotinylated-DNA fragment is added, resulting in the formation of a specific antigen-Ab-DNA conjugate. The attached marker DNA can be amplified by PCR with appropriate primers. Some results have shown that $\sim 10^{5}$ fold increase in sensitivity over an alkaline phosphataseconjugated ELISA is obtained. This approach, with slight modifications, has been used to detect a variety of antigens, including a human protooncogene protein and tumour necrosis factor $\alpha$.

Although the immuno-PCR technique has some advantages over traditional methods of protein detection, such as increase in sensitivity, there still exist several notable limitations to its use. One of the major limitations of immuno-PCR lies in the nonlinear amplification ability of PCR, which limits this technique as a quantitative detection method. Some of these problems have been overcome with a relatively isothermal rolling circle DNA amplification technique (RCA). As demonstrated in Figure 4(B) (Zhang et al. 2001), T7 RNA amplification resolves these problems and shows a linear relationship between protein expression and an expression indicator such as luciferase.

\section{Methods and application of genomic expression from single cells}

Methods of genomic expression from single cells. Single-cell gene expression analysis can be carried out both at the specific profile and global genome profile. In situ hybridization and rtPCR belong to the specific profile. In situ PCR combined with immunohistochemical detection is frequently used as a measurement of single-cell gene activity (Gey et al. 1999). Multiplex rtPCR is also effective for observing gene expression at the single-cell level (Hahn et al. 2002). At present, rtPCR using real-time detection of PCR products can quantify gene expression at the singlecell level with reduced risk for artefacts resulting from contamination or illegitimate transcript amplification (Liss, 2002). However, because the primers are pre-selected, expression profiles will not contain previously unreported transcripts or novel sequences.

Global genome profile expression analysis at the single-cell level holds new promise to analyze disease pathogenesis and tumorigenesis. At present, four techniques are utilized to advance the global genome profile of a single cell (in addition to the previously described specific profiles such as in situ hybridization and multiplex rtPCR). These global genome profiles include differential display, subtractive cloning, microarray, and protein array. As shown in Figure $\underline{2}$ and Figure 3, differential display and subtractive cloning can be employed with a small number of cells in which the resolution is from one cell to $10^{4}$ cells (Chen and Talmage, 1999). Because both of these methods may have an artefact contamination after amplification, it may result in variable genome expression at the single-cell level. As discussed above, we introduced a strategy combining amplifying RNA, randomized primers (with restriction terminals for cloning into plasmid) and subtractive hybridization (for eliminating some artefacts), which has successfully been used in genome expression at single-cell level. Although our method still has a problem in screening the genome, that is, some 3' bias, after sequencing the genome at 3' terminal fragment, GenBank analysis can allow us to eventually determine full-length genome prediction ( $\mathrm{Li}$ et al. 2000; Li et al. 2002; Zhang et al. 2004). Here, some explanation and details shown as above (such as including A: designs of random primers with restriction enzyme site, B: cDNA amplification, C: cloning into plasmid and storage of library and D: subtractive hybridization using reference cell cDNA), we illustrate the basic protocol in

Table 3. Functional genomics analysis for single cell or small cell number.

\begin{tabular}{|c|c|c|c|c|c|}
\hline Methods & Minimum Cell & Throughput & Sequencing & Application & Disadvantage \\
\hline \multicolumn{6}{|l|}{ rtPCR base } \\
\hline Multiplex rtPCR & single cell & poor & N/A & specific gene & one cell $<24$ genes \\
\hline In situ rtPCR & single cell & poor & N/A & specific gene & one cell $<5$ genes \\
\hline \multicolumn{6}{|l|}{ Gel base } \\
\hline DD & single cells & medium & low & $\begin{array}{l}\text { Parallel gene } \\
\text { expression }\end{array}$ & false positive \\
\hline \multicolumn{6}{|l|}{ Colony base } \\
\hline Subtractive cloning & $10^{0}-10^{4}$ cells & medium & low & $\begin{array}{l}\text { Parallel gene } \\
\text { expression }\end{array}$ & not typical parallel \\
\hline \multicolumn{6}{|l|}{ Hybridization base } \\
\hline Microarray & $\begin{array}{l}\text { single-cell } \\
\text { developing }\end{array}$ & High & N/A & \begin{tabular}{|l} 
Parallel gene \\
expression
\end{tabular} & no sensitivity \\
\hline \multicolumn{6}{|l|}{ Protein base } \\
\hline Protein array & $\begin{array}{l}\text { single-cell } \\
\text { developing }\end{array}$ & High & N/A & $\begin{array}{l}\text { Parallel protein } \\
\text { expression }\end{array}$ & no sensitivity \\
\hline
\end{tabular}


Li, B.

Figure 5.

DNA microarrays used for single-cell DNA have emerged. One method involves modifying some procedures to increase resolution such as aRNA and cDNA amplification, and another involves remodelling microarray platform materials. Because modified microarrays still suffer from inadequate resolution, other single-cell rtPCR or DD are required to confirm the results (Bahn et al. 2001). In remodelling microarray platform materials, recently, a high-density fibre optic DNA microarray has been developed, in which there are 6,000 to 50,000 fused optical fibres, and each fibre terminates with an etched well. This array platform provides many advantages over other array formats. These microarrays contain the smallest feature sizes so that it is believed that the fabrication protocol enables, in the future, their expansion into single cell-based assays (Epstein et al. 2003).

Protein arrays based on antibody-binding technology shall emerge by development of immuno-PCR and T7 RNA amplification to screen protein expression at the single cell level. If intact Abs, ScFv fragments or exocyclic peptidebased complementarity determining region (CDR) subunits can serve as antigen detectors in the protein array, it can likely facilitate the development of a robotic platform for proteomics. If a large scale of antibodies can be produced, the usage of this approach will have a good potential.

Application of genomic expression from single cells. Gene expression profiles of single cells are providing tremendous insights into disease pathogenesis, especially in tumorigenesis. Eberwine reported gene expression in a single live neuron, and a successful application involving rtPCR appeared (Eberwine, 1992; Eberwine, 1996). The specific profile has extended from single-gene expression to multiplex PCR, from regular expression to in situ rtPCR, and from routine rtPCR to realtime rtPCR. For instance, some scientists recently reported that computational fluorescence microscopy with multiplex probes can analyze the expression patterns of eleven genes in individual serum-stimulated cultured cells (Levsky et al. 2002).

For global profiles, the progress is very slow due to current technological limitations. Most scientists screen global profiles, as discussed above, by using microarrays from a large number of cells and then confirming them by analyzing the specific profile at the single-cell level by using rtPCR or differential display. For example, differential display was first utilized in the profile of a single CD3 positive cell in 1998 (Renner et al. 1998). A single sea urchin egg was initially analyzed via microarray in 1998 (Michael and Walt, 1999), and later, DNA microarray was used to analyze the profile of a single plant cell (Brandt et al. 2002). In 2000, we reported a strategy to observe the global profile of a small number of T-cells (10 to 100 cells) (Li et al. 2000). Recently, some investigators have suggested using tiny tissue samples from lasercaptured microdissection to analyze genomic profiles, especially in complex multifactorial diseases such as neuropsychiatric disorders (Ginsberg and Che, 2002). According to the idea of micro-dissection to obtain the tiny tissue or single cell, a genomic change of aberrant crypt foci have been successfully observed in our laboratory $(\mathrm{Li}$, 2002).

\section{FUTURE OF GENOMICS AT THE SINGLE-CELL LEVEL}

Although technical developments and clinical application in single-cell gene expression have been established and developed, the techniques and applications still need to be optimized. A mature genome expression analysis at the single-cell level needs the following: (1) a good method for

\begin{tabular}{|l|l|l|l|}
\hline Single cell & $\begin{array}{l}\text { Cloning into } \\
\text { vector for } \\
\text { ansis } \\
\text { storage }\end{array}$ & $\begin{array}{l}\text { Subtractive } \\
\text { hybridization by } \\
\text { reference cDNA }\end{array}$ \\
$\begin{array}{l}\text { Representative } \\
\text { search and } \\
\text { sequencing }\end{array}$ & $\begin{array}{l}\text { Biomformatic } \\
\text { analysis }\end{array}$ & $\begin{array}{l}\text { Northern blot } \\
\text { confirming }\end{array}$ \\
\hline
\end{tabular}

Figure 5. Genomic expression analysis at single cells.

\# shown at Figure 3.

* illuminated at Figure 2IV. 
isolating pure homogenous cells; (2) intact bio-molecule harvest for mRNA and proteins along with a high-fidelity amplification system; and (3) a sensitive method to detect the biomarker at the single-cell level. As we indicated above, no single method can currently satisfy all of these requirements. For example, in situ hybridization and multiplex rtPCR are limited to the analysis of a known profile. Also, DNA microarrays require the development of more sensitive platform materials. In other words, after developing immuno-PCR and T7 RNA amplification, it is possible to screen protein expression at single cell levels, but production of many thousands of intact protein Abs and peptide Abs still face great challenges. We have designed randomized primers and combined strategies including amplifying RNA, cloning into plasmids and subtractive hybridization to minimize some artifacts, and this strategy has been successfully applied from several hundred cells to a single-cell level. However, the problem with 3' bias still needs to be resolved.

Fortunately, many scientists and companies are focused on overcoming these challenges. It is believed that single-cell global genome profiling will become an important tool for scientists and physicians to study pathogenesis, early clinical diagnosis and treatment in the near future.

\section{REFERENCES}

AMBION CATALOG. Macromolecular Components of $E$. coli and Hela Cells. 2004, p. 192.

BAHN, S.; AUGOOD, S.J.; RYAN, M.; STANDAERT, D.G.; STARKEY, M. and EMSON, P.C. Gene expression profiling in the post-mortem human brain - no cause for dismay. Journal of Chemistry Neuroanatomy, 2001, vol. 22, no. 1-2, p. 79-94.

BOSCH, I.; MELICHAR, H. and PARDEE, A.B. Highly sensitive differential display (DD) using small amounts of RNA. Qiagen News. 2000, no. 3, p. 3.

BOULTWOOD, J. and WAINSCOAT, J.S. Clonality in the myelodysplastic syndromes. International Journal of Hematology, June 2001, vol. 73, no. 4, p. 411-415.

BRANDT, S.; KLOSKA, S.; ALTMANN, T. and KEHR, J. Using array hybridization to monitor gene expression at the single cell level. Journal of Experimental Botany, December 2002, vol. 53, no. 379, p. 2315-2323.

CARULLI, J.P.; ARTINGER, M.; SWAIN, P.M.; ROOT, C.D.; CHEE, L.; TULIG, C.; GUERIN. J.; OSBORNE, M.; STEIN, G.; LIAN, J. and LOMEDICO, P.T. High throughput analysis of differential gene expression. Journal of Cellular Biochemistry, suppl., 1998, vol. 30-31, p. 286296.

CHEN, Y. and TALMAGE, D.A. Subtractive cDNA cloning and characterization of genes induced by all-trans retinoic acid. Annals of New York Academy Sciences, 1999, vol. 886, p. 225-228.

CLAUDIO, J.O.; LIEW, C.C.; DEMPSEY, A.A.; CUKERMAN, E.; STEWART, A.K.; NA, E.; ATKINS, H.L.; ISCOVE, N.N. and HAWLEY, R.G. Identification of sequence-tagged transcripts differentially expressed within the human hematopoietic hierarchy. Genomics, May 1998, vol. 50, no. 1, p. 44-52.

CORDWELL, S.J.; NOUWENS, A.S.; VERRILLS, N.M.; BASSEAL, D.J. and WALSH, B.J. Subproteomics based upon protein cellular location and relative solubilities in conjunction with composite two-dimensional electrophoresis gels. Electrophoresis, April 2000, vol. 21, no. 6, p.1094-1103.

DEAN, F.B.; HOSONO, S.; FANG, L.; WU, X.; FARUQI, A.F.; BRAY, WARD P.; SUN, Z.; ZONG, Q.; DU, Y.; DU, J.; DRISCOLL, M.; SONG, W.; KINGSMORE, S.F.; EGHOLM, M. and LASKEN, R.S. Comprehensive human genome amplification using multiple displacement amplification. Proceedings of National Academy of Sciences of the United States of America, 2002, vol. 99, no. 8, p. 5261-5266.

DIXON, A.K.; RICHARDSON, P.J.; LEE, K.; CARTER, N.P. and FREEMAN, T.C. Expression profiling of single cells using 3 prime end amplification (TPEA) PCR. Nucleic Acids Research, October 1998, vol. 26, no. 19, p. 44264431.

EBERWINE, J. Amplification of mRNA populations using aRNA generated from immobilized oligo(dT)-T7 primed cDNA. Biotechniques, April 1996, vol. 20, no. 4, p. 584591.

EBERWINE, J.; YEH, H.; MIYASHIRO, K.; CAO, Y.; NAIR, S.; FINNELL, R.; ZETTEL, M. and COLEMAN, P. Analysis of gene expression in single live neurons. Proceedings of National Academy of Sciences of the United States of America, April 1992, vol. 89, no. 7, p. 3010-3014.

EMMERT-BUCK, M.R.; BONNER, R.F.; SMITH, P.D.; CHUAQUI, R.F.; ZHUANG, Z.; GOLDSTEIN, S.R.; WEISS, R.A. and LIOTTA, L.A. Laser capture microdissection. Science, November 1996, vol. 274, no. 5289, p. 998-1001.

EPSTEIN, J.R.; LEUNG, A.P.; LEE, K.H. and WALT, D.R. High-density, microsphere-based fiber optic DNA microarrays. Biosensors and Bioelectronics, May 2003, vol. 18, no. 5-6, p. 501-546.

FEND, F.; EMMERT-BUCK, M.R.; CHUAQUI, R.; COLE, K.; LEE, J.; LIOTTA, L.A. and RAFFELD, M. Immuno-LCM: laser capture microdissection of immunostained frozen sections for mRNA analysis. American Journal of Pathology, June 1999, vol. 154, no. 6, 


\section{Li, B.}

p. $1857-1866$.

FORDE, C.E. and MCCUTCHEN-MALONEY, S.L. Characterization of transcription factors by mass spectrometry and the role of SELDI-MS. Mass Spectrometry Review, November-December 2002, vol. 21, no. 6, p. 419-439.

GEY, A.; HAMDI, S.; VIELH, P.; MEHTALI, M.; FRIDMAN, W.H. and TARTOUR, E. Development of a direct in situ RT-PCR method using labeled primers to detect cytokine mRNA inside cells. Journal of Immunology Methods, July 1999, vol. 227, no. 1-2, p. 149-160.

GINSBERG, S.D. and CHE, S. RNA amplification in brain tissues. Neurochemistry Research, 2002, vol. 27, no. 10, p. 981-992.

HAHN, S.; ZHONG, X.Y. and HOLZGREVE, W. Single cell PCR in laser capture microscopy. Methods of Enzymology, 2002, vol. 356, p. 295-301.

KLEBE, R.J.; RODRIGUEZ, S.A.; VERBEEK, M.L. and GIAMBERNARDI, T.A. RT-PCR without RNA isolation. Biotechniques, December 1996, vol. 21, no. 6, p. 10941100.

KIM, J.H. Bioinformatics and genomic medicine. Genetics in Medicine, November-December 2002, vol. 4, no. 6, p. 62S-65S.

LEVSKY, J.M.; SHENOY, S.M.; PEZO, R.C. and SINGER, R.H. Single-cell gene expression profiling. Science, August 2002, vol. 297, no. 5582, p. 836-840.

LI, B.; PERABEKAM, S.; LIU, G.; YIN, M.; SONG, S. and LARSON, A. Experimental and bioinformatics comparison of gene expression between T cells from TIL of liver cancer and $\mathrm{T}$ cells from UniGene. Journal of Gastroenterology, 2002, vol. 37, no. 4, p. 275-282.

LI, B.; CHANG, T.; LARSON, A. and DING, J. Identification of mRNAs expressed in tumor-infiltrating lymphocytes by a strategy for rapid and high throughput screening. Gene, September 2000, vol. 255, no. 2, p. 273279.

LILLEBERG, S.L. In-depth mutation and SNP discovery using DHPLC gene scanning. Current Opinion of Drug Discovery and Development, 2003, vol.6, p. 237-252.

LISS, B. Improved quantitative real-time RT-PCR for expression profiling of individual cells. Nucleic Acids Research, 2002, vol. 30, no. 17, p. e89.

MEEHAN, W.J. and WELCH, D.R. Breast cancer metastasis suppressor 1: update. Clinical Experimental Metastasis, 2003, vol. 20, no. 1, p. 45-50.
MEIER-RUGE, W.; BIELSER, W.; REMY, E.; HILLENKAMP, F.; NITSCHE, R. and UNSOLD, R. The laser in the Lowry technique for microdissection of freezedried tissue slices. Histochemistry Journal, July 1976, vol. 8, no. 4, p. 387-401.

MCKIE, A.; SAMUEL, D.; COHEN, B. and SAUNDERS, N.A. Development of a quantitative immuno-PCR assay and its use to detect mumps-specific IgG in serum. Journal of Immunology Methods, March 2002, vol. 261, no. 1-2, p. 167-175.

MORITA, M.; HACHISUKA, H. and SASAI, Y. Detection of genomic DNA with a high sensitivity in tissue sections using a two step cycling in situ PCR procedure. Kurume Medical Journal, 1994, vol. 41, no.4, p. 215-220.

MICHAEL, K.L. and WALT, D.R. Combined imaging and chemical sensing of fertilization-induced acid release from single sea urchin eggs. Analytical Biochemistry, September 1999, vol. 273, no. 2, p. 168-178.

MURRAY, J.; GILKERSON, R. and CAPALDI, R.A. Quantitative proteomics: the copy number of pyruvate dehydrogenase is more than 10(2)-fold lower than that of complex III in human mitochondria. FEBS Letter, October 2002, vol. 9, no. 2-3, p. 173-178.

OPPERMANN, M.; COLS, N.; NYMAN, T.; HELIN, J.; SAARINEN, J.; BYMAN, I.; TORAN, N.; ALAIYA, A.A.; BERGMAN, T.; KALKKINEN, N.; GONZÀLEZDUARTE, R. and JÖRNVALL, H. Identification of foetal brain proteins by two-dimensional gel electrophoresis and mass spectrometry. Comparison of samples from individuals with or without chromosome 21 trisomy. European Journal of Biochemistry, 2000, vol. 267, p. 47134719.

ORMEROD, M. Flow Cytometry: A Practical Approach. Oxford University Press, Oxford, UK. 2000, p. 276. ISBN 0199638241.

REN, Z.P.; SALLSTROM, J.; SUNDSTROM, C.; NISTER, M. and OLSSON, Y. Recovering DNA and optimizing PCR conditions from microdissected formalinfixed and paraffin-embedded materials. Pathobiology, 2000, vol. 68, no. 4-5, p. 215-217.

RENNER, C.; TRUMPER, L.; PFITZENMEIER, J.P.; LOFTIN, U.; GERLACH, K.; STEHLE, I.; WADLE, A. and PFREUNDSCHUH, M. Differential mRNA display at the single-cell level. Biotechniques, May 1998, vol. 24, no. 5, p. 720-722.

SCHUTZE, K. and LAHR, G. Identification of expressed genes by laser-mediated manipulation of single cells. Nature Biotechnology, August 1998, vol. 16, no. 8, p. 737742. 
SHAKNOVICH, R.; CELESTINE, A.; YANG, L. and CATTORETTI, G. Novel relational database for tissue microarray analysis. Archives of Pathology and Laboratory Medicine, 2003, vol. 127, no. 4, p. 492-494.

STEINERT, R.; BUSCHMANN, T.; VAN DER LINDEN, M.; FELS, L.M.; LIPPERT, H. and REYMOND, M.A. The role of proteomics in the diagnosis and outcome prediction in colorectal cancer. Technology in Cancer Research and Treatment. August 2002, vol. 1, no. 4, p. 297-304.

TOELLNER, K.M.; GULBRANSON-JUDGE, A.; TAYLOR, D.R.; SZE, D.M. and MACLENNAN, I.C. Immunoglobulin switch transcript production in vivo related to the site and time of antigen-specific B cell activation. Journal of Experimental Medicine, May 1996, vol. 183, no. 5, p. 2303-2312.

TRENDELENBURG, G.; PRASS, K.; PRILLER, J.; KAPINYA, K.; POLLEY, A.; MUSELMANN, C.; RUSCHER, K.; KANNBLEY, U.; SCHMITT, A.O.; CASTELL, S.; WIEGAND, F.; MEISEL, A.; ROSENTHAL, A. and DIRNAGL, U. Serial analysis of gene expression identifies metallothionein-II as major neuroprotective gene in mouse focal cerebral ischemia. The Journal of Neuroscience, July 15, 2002, vol. 22, no. 14, p. 5879-5888.

WEIGL, B.H.; BARDELL, R.L. and CABRERA, C.R. Lab-on-a-chip for drug development. Advanced Drug Delivery Reviews, February 2003, vol. 55, no. 3, p. 349377.

WOOD, G.S. Analysis of clonality in cutaneous T cell lymphoma and associated diseases. Annals of New York Academy Sciences, 2001, vol. 941, p. 26-30.

ZHANG, W.; QU, Y.; PRETLOW TP. and LI, B. Gene cloning and genomic expression analysis from ACF-A study on pre-colon cancer. In: Cancer Genetics and Tumor suppressor genes. (18 - 22 August, 2004, New York, USA). Cold Spring Harbor Laboratory, 2004, p. 234.

ZHANG, H.T.; KACHARMINA, J.E.; MIYASHIRO, K.; GREENE, M.I. and EBERWINE, J. Protein quantification from complex protein mixtures using a proteomics methodology with single-cell resolution. Proceedings of National Academy of Sciences of the United States of America, May 2001, vol. 98, no. 10, p. 5497-5502.

Note: This paper for a memory of Dr. Harvey D. Preisler, who contributed his whole life to study tumorigenesis of AML, He was a director of Rush Cancer Institute from 1990 to 2002. 